\author{
Z.D. Kulbayeva, D.A. Klyuyev*, S.S. Kaliyeva \\ Medical University of Karaganda, Kazakhstan \\ *Corresponding author: klyuev@qmu.kz
}

\title{
Neurological symptoms and complications of COVID-19. Minireview
}

\begin{abstract}
Since the first official case of COVID-19 in China in December 2019, researchers have been trying to uncover the mechanism of action of the severe acute respiratory syndrome Coronavirus 2 (SARS-CoV-2), which attacks several organs in addition to the lungs and causes circulatory changes that can lead to death not only because of lung failure but also failure of other organs. The aim of this study is to find out the neurological consequences of COVID-19. A systematic review of the literature was concretized by mobilizing the descriptors: "SARS-CoV-2", "coronavirus infections" and "Neurological Consequences". Although the effects of SARSCoV-2 on the lung are exemplary and frightening, the long-term effects on the nervous system may be greater and even more overwhelming, as the regeneration of nerve tissue is difficult and can lead to general disability, as the nervous system coordinates the functions of the entire body. Considered studies point out the presence of various injuries (mild or severe) to central nervous system because of COVID-19 infection. It can be said that the studies all agree on the possibility of existing neurological sequelae and a majority emphasize on the need for further investigation.
\end{abstract}

Keywords: coronavirus, SARS-CoV-2, neurological consequences, coronavirus pathogenesis.

\section{Introduction}

Often, infectious diseases are the cause of local outbreaks. With the active spread, these infectious diseases develop into epidemics, pandemics. In December 2019, in the city of Wuhan, China, for the first time, cases of a previously unknown infection characterized by severe acute respiratory syndrome were recorded. As a result, it was found that the causative agent is RNA containing the SARS-CoV-2 (COVID-19) virus, according to WHO data [1]. Earlier SARS-CoV and MERS-CoV epidemics were registered as CoV. However, because of its virulence and pathogenicity the SARS-CoV-2 virus was declared as pandemic in December 2020. To date, more than 140 million cases have been registered worldwide, while in Kazakhstan this figure is 367 thousand.

Most often, coronavirus infection manifests itself with respiratory syndrome, and more attention is paid to studying these issues. Nonetheless, neurological manifestations were reported in 30-80\% of patients with COVID-19. Nervous system-related symptoms may include headache, dizziness, impaired consciousness, agitation, acute stroke, seizures, ataxia, and peripheral nervous system symptoms such as syndrome GuillainBarre, changes in the sense of smell and taste, as well as painful neuropathy [2-7]. According to studies of previous respiratory pandemics, neurological symptoms can occur both in the acute period and in the longterm. Thus, after the Spanish Flu pandemic, the number of cases of Parkinson's disease, lethargic encephalitis increased. After SARS-CoV, MERS, the incidence of encephalitis, encephalopathies, neuromuscular, demyelinating diseases, Guillain-Barre grew [8-11].

To date, the literature contains data on the manifestation, features of the clinical course of coronavirus infection, including nervous system disorders. However, there is insufficient information about the long-term consequences that may develop 3-6 months or more after the infection. The study of the consequences will allow evaluating the effectiveness of the treatment, as well as improve the prevention of undesirable consequences.

Pathogenesis of coronavirus infection. In December 2019, hospitals in Wuhan began to receive patients with atypical pneumonia. During the examination of patients, their bronchopulmonary passage was studied. A virus, later named SARS-CoV-2, was detected in the passage of patients. Earlier, there were local outbreaks of coronavirus infection, but this mutation led to a pandemic. At the moment, the issue of the pathogenesis of the development of coronavirus infection remains one of the most relevant. There are several theories about the mechanisms of infection development.

ACE2 receptor. Currently, there are several hypotheses about the mechanisms that cause the signs and symptoms associated with SARS-CoV-2 infection. According to a number of studies, coronavirus infection interacts with ACE2 receptors, which are found in the cells of the nervous system, in muscles and respond to 
the regulation of blood pressure in the RAS system. This type of receptor is also found in the brain, namely in the brain stem, in the medulla oblongata in the thalamus, which makes them a potential target for coronavirus infection $[12,13]$.

Direct damage to nerve cells. According to the literature, some of the symptoms of coronavirus infection are anosmia, aughesia. The olfactory nerve is the entrance gate of the virus to the central nervous system. The peculiarity of the olfactory nerves and the olfactory bulb is that this nerve is like a channel between the nasal epithelium and parts of the brain, especially the brain stem [14]. In the brain stem, there are centers that regulate the work of the heart and lungs, which can also cause a severe course of the disease, as well as the development of consequences against the background of a transferred coronavirus infection [15-17].

Immune response. One of the most relevant hypotheses is systemic inflammation. As a result of the immune response to the pathogen, there is an increase in the secretion of inflammatory mediators, cytokines, which leads to a cytokine storm and systemic damage. This phenomenon can lead to damage to endothelial cells and subsequent changes in the permeability of the blood-brain barrier. Infection can also cause autoimmune encephalitis due to the presence of autoantibodies attacking neurons and endothelial cells in blood vessels, thus, activating the hypothalamic-pituitary-adrenal axis, which causes stress and other physiological changes due to excessive activation of glucocorticoid effectors and their receptors [18].

Clinic for coronavirus infection. This viral disease is highly contagious and rapidly spreading. The main routes of transmission of coronavirus infection are airborne droplets and contact.

Initial symptoms of coronavirus infection include: fever, cough, shortness of breath, myalgia or fatigue, headache. In a number of patients, the manifestation occurs with neurological symptoms. Neurological manifestations were reported in 30-80 \% of patients with COVID-19. The most common symptoms are headache, myalgia, dizziness, fatigue, and sleep disorders. Therefore, a study was conducted in which 214 patients were admitted with coronavirus infection to a hospital in Wuhan, $36.4 \%$ had neurological manifestations, of which: CNS $24.8 \%$, peripheral NS $10.7 \%$ and musculoskeletal $10.7 \%$ [4].

In the literature, cases of manifestation of coronavirus infection with encephalitis in a 56-year-old patient from Wuhan were described $[19,20]$. The patient was admitted to the intensive care unit and presented with a reduced level of consciousness, so, a CT scan of the brain was performed, which was normal. The diagnosis of encephalitis was confirmed by isolation of SARS-CoV-2 from the cerebrospinal fluid by genomic sequencing. There was also a case of acute hemorrhagic necrotizing encephalopathy in a patient with a coronavirus infection who developed symptoms of fever, cough, and changes in mental state. The diagnosis was made by detecting SARS-CoV-2 by PCR in a nasopharyngeal sample. CT scans of the brain revealed a symmetrical and bilateral area of hypodensity in the medial nucleus of the thalamus. MRI showed an increase in hemorrhagic lesions after contrast injection, multifocal and symmetrical, ring-shaped both in the thalami, insula and medial temporal lobe region. Acute necrotizing encephalopathy, although relatively rare, is a complication described in some viral infections, including the influenza virus. The authors suggest that its pathogenesis will be associated with the cytokine storm syndrome described by coronavirus infection [21].

Based on the course the following degrees of severity of coronavirus infection are distinguished: mild, moderate, severe, and critical. Patients with mild severity are characterized by an asymptomatic course, or a mild clinical manifestation without radiological changes. Patients with moderate severity are characterized by lung damage up to $25 \%$, saturation is not lower than $93 \%$ moderate clinical manifestations. Patients with a severe degree are characterized by lung damage up to $75 \%$, saturation up to $90 \%$, as well as pronounced clinical manifestations. In the case of a critical degree, lung damage is more than $75 \%$, saturation is less than $90 \%$, and it includes multiple organ damage [22].

As with any infectious process, coronavirus infection is characterized by periods of development of the disease. The incubation period, which on average lasts from 2 to 14 days, is characterized by the replication of the virus in the body, usually without any clinical manifestations. The initial period, as a rule, is $1-7$ days with characteristic clinical manifestations, as well as laboratory changes. The duration of the disease is divided into two main phases: early and late pulmonary phases. The early pulmonary phase lasts on average from 8-14 days, and the late pulmonary phase lasts 15-28 days. The main difference between the early and late pulmonary phases is the severity of the clinical course [23].

According to the studies, there are also 3 main stages, which are characterized by both clinical and laboratory changes. The first stage is the stage of early infection. It is characterized by the introduction of the virus into the lung parenchyma through the ACE2 receptor. The main marker of this stage is lymphocytopenia. The second stage is pulmonary. It is characterized by the development of viral pneumonia, lymphopenia, 
and an increase in transaminases, such as CRP. As a rule, the patient is hospitalized at this stage. The third stage is hyperinflammation - the most severe stage of the disease. It is characterized by the development of a cytokine storm up to ARDS, MVS. At this stage, patients are admitted to the intensive care unit with an increase in all markers of inflammation in the blood. At the same time, other organs and systems of the body are damaged at this stage [24].

Consequences of coronavirus infection. According to the literature, coronavirus infection does not pass without a trace. So, in a study of the long-term consequences of infection, it was found that $63 \%$ of the examined people developed general muscle weakness, $26 \%$ had sleep disorders, and $23 \%$ had anxiety. Also, most patients have respiratory system disorders. To a greater extent, patients who have suffered from a severe coronavirus infection are more susceptible to adverse consequences. At the stage of patient selection, cases of fatal outcome were registered as a result of insufficiency on the part of various organs and systems. At the same time, there were cases of repeated hospitalization of patients due to an increase in complaints and deterioration of the condition [25].

Since the outbreak of coronavirus infection began relatively recently, so far all estimates of long-term consequences are preliminary and hypothetical. Based on the experience of previous outbreaks from perspective of many researchers the most pronounced consequences will be from the respiratory system. Considering the results of the studies, it was found that among patients who had SARS-CoV (a history of SARS-CoV a year, two and fifteen years ago), persistent changes in the lungs, foci of fibrosis were revealed. These changes led to impaired breathing and quality of life, respectively [26, 27].

Coronavirus infection is characterized by a rapid course and multiple organ damage. According to a number of authors, the interaction of the virus with the ACE2 receptor contributes to damage to the kidneys, heart, blood vessels, nervous system, and other organs. As a result, patients after coronavirus infection develop diabetes mellitus, arterial hypertension, thrombosis, and diseases of the nervous system. However, it is not fully known whether coronavirus infection causes the development of somatic pathologies or only contributes to the manifestation of a disease that has already been latent [28].

Viruses, including respiratory viruses, can enter the central nervous system (CNS) (neuroinvasion), infect both neurons and glial cells (a property known as neurotropism), and cause various neurological pathologies. According to the scientists, coronavirus infection also has neuroinvasive properties. Such assumptions were made on the basis of the experience of previous coronavirus infections, clinical manifestations, and the creation of models of animal infection with coronavirus infection [29].

To date, the issue of the frequency of occurrence of neurological complications remains relevant. It is noted that patients who have suffered a coronavirus infection in severe form are more likely to develop neurological consequences. Besides the background of coronavirus infection, patients may develop brain edema, destruction of neurons.

Anosmia and taste disorders are common in people with coronavirus infection, and can occur suddenly [30]. The prevalence of olfactory and gustatory dysfunctions was analyzed in the case register of 12 European hospitals. The study involved 417 patients with mild to moderate coronavirus infection. Patients completed taste and smell disorder questionnaires based on the nutrition and health survey and a short version of the Olfactory Taste and Smell Disorder questionnaire. The most common symptoms were cough, myalgia, and loss of appetite. Olfactory and gustatory disorders were reported in $85.6 \%$ and $88 \%$ of patients, respectively, and olfactory dysfunction was the initial symptom in $12 \%$ [31].

Patients with coronavirus infection suffer from severe hypoxia, which is a risk factor for encephalopathy. In a study by Mao et al., $15 \%$ of patients with severe coronavirus infection had a disturbed level of consciousness, while only $2.4 \%$ of patients with mild coronavirus infection had a disturbed level of consciousness [4]. Also, according to a number of authors, the immune-mediated mechanism of damage in coronavirus infection contributes to the development of acute cerebral circulatory disorders. Most often, patients with concomitant pathology, as well as patients who have suffered a severe coronavirus infection, are subject to impaired cerebral circulation.

The literature also describes cases of damage to the peripheral nervous system against the background of coronavirus infection. A case of the syndrome Guillain-Barre, associated with SARS-CoV-2 infection, was described in a 62-year-old female patient who had motor weakness in the lower extremities. The study of cerebrospinal fluid showed an increase in protein $(124 \mathrm{mg} / \mathrm{dl})$ and the absence of cells. Neurophysiological examination showed an increase in distal delays and the absence of F-waves, indicating a form of demyelinating GBS. The authors suggest that the patient was infected with SARS-CoV-2 at the beginning of HBS symptoms, as she had lymphopenia and thrombocytopenia [31]. 


\section{Conclusions}

To date, the literature describes multiple cases of damage to organs and systems, including the nervous system, during coronavirus infection. However, there is still insufficient data on the long-term effects of coronavirus infection on the nervous system. Overall, it is not fully known whether coronavirus infection is the root cause or a factor that stimulates the activation of latent processes. In this regard, this issue remains relevant and requires further study to prevent adverse consequences.

\section{Acknowledgements}

This research has been funded by the Science Committee of the Ministry of Education and Science of the Republic of Kazakhstan (Grant AP09562567).

\section{References}

1 World Health Organization Coronavirus disease (COVID-19) situation report 102. — 2020. — Retrieved from: https://www.who.int/emergencies/diseases/novel-coronavirus-2019/situation-reports/.

2 Filatov A. Neurological complications of coronavirus disease (COVID-19): encephalopathy / A. Filatov, P. Sharma, F. Hindi, P.S. Espinosa // Cureus. - 2020. — Vol. 12 (3). — P. 7352. https://doi.org/10.7759/cureus.7352.

3 Munster V. A novel coronavirus emerging in China-key questions for impact assessment / V. Munster, M. Koopmans, N. Doremalen // N. Engl. J. Med. — 2020. — Vol. 382, Issue 8. - P. 692-694. https://doi.org/10.1056/NEJMp2000929

4 Mao L. Neurologic manifestations of hospitalized patients with coronavirus disease 2019 in Wuhan, China / L. Mao, H. Jin, M. Wang // JAMA Neurol. — 2020. — e201127. https://doi.org/10.1001/jamaneurol.2020.1127

5 Spinato G. Alterations in smell or taste in mildly symptomatic outpatients with SARS-CoV-2 infection / G. Spinato, C. Fabbris, J. Polesel, $\quad$ D. Cazzador, $\quad$ D. Borsetto, C. Hopkins, $\quad$ P. Boscolo-Rizzo // JAMA. $\quad-\quad 2020 . \quad-\quad$ e206771. https://doi.org/10.1001/jamaneurol.2020.6771

6 Helms J. Neurologic features in severe SARS-CoV-2 infection / J. Helms, S. Kremer, H. Merdji, M. Schenck, C. Kummerlen, O. Collange, C. Boulay, S. Fafi-Kremer, M. Ohana, M. Anheim, F. Meziani // N. Engl. J. Med. — 2020. c2008597. https://doi.org/10.1056/NEJMc2008597

7 Kokil Y.D. Guillain-Barré syndrome associated with SARS-CoV-2 / Y.D. Kokil, K.T.M. Raj, M. Samprathi, M. Sridhar, R. Adiga, P. Vemgal // The Indian Journal of Pediatrics. — 2021. — Vol. 88, Issue 5. https://doi.org/10.1007/s12098-021-03684-x

8 Kim J.E. Neurological complications during treatment of middle east respiratory syndrome / J.E. Kim, J.H. Heo, H.O. Kim, S.H. Song, S.S. Park, T.H. Park, J.Y. Ahn, M.K. Kim, J.P. Choi // J. Clin. Neurol. - 2017. — Vol. 13. - P. $227-233$. https://doi.org/10.3988/jen.2017.13.3.227

9 Manjunatha N. The neuropsychiatric aspects of influenza/swine flu: A selective review / N. Manjunatha, S.B. Math, G.B. Kulkarni // Ind. Psychiatry J. — 2011. — Vol. 20. — P. 83-90.

10 Tsai L. Neuromuscular disorders in severe acute respiratory syndrome / L. Tsai, S. Hsieh, C. Chao // Arch. Neurol. — 2004. — Vol. 61. - P. 1669-1673.

$11 \mathrm{Wu}$ H. Symptoms and occurrences of narcolepsy: a retrospective study of 162 patients during a 10-year period in Eastern China / H. Wu, J. Zhuang, W.S. Stone, L. Zhang, Z. Zhao, W. Zongwen, Y. Yang, L. Xiang, X. Zhao, Z. Zhai // Sleep Med. — 2014. — Vol. 15 (6). P. 607-613. https://doi.org/10.1016/j.sleep.2013.12.012

12 Miller A. The renin-angiotensin system in cardiovascular autonomic control: recent developments and clinical implications / A. Miller, A. Arnold // Clinical Autonomic Research. — 2019. — Vol. 29, Issue 2. — P. 231-43. https://doi.org/10.1007/210286018-0572-5

13 Gowrisankar Y. Angiotensin II regulation of angiotensin-converting enzymes in spontaneously hypertensive rat primary astrocyte cultures / Y. Gowrisankar, M. Clark // Journal of Neurochemistry. - 2016. - Vol. 138, Issue 1. - P. 74-85. https://doi.org/10.1111/jnc.13641

14 Koyuncu O. Virus infections in the nervous system / O. Koyuncu, L. Hogue, L. Enquist // Cell host \& Microbe. — 2013. Vol. 13, No. 4. - P. 379-93.

15 Steardo L. Neuroinfection may contribute to pathophysiology and clinical manifestations of COVID-19 / L. Steardo, R. Zorec, A. Verkhratsky // Acta Physiologica. — 2020. — Vol. 229 (3). — e13473. https://doi.org/10.1111/apha.13473

16 Netland J. Severe acute respiratory syndrome coronavirus infection causes neuronal death in the absence of encephalitis in mice transgenic for human ACE2 / J. Netland, D. Meyerholz, S. Moore // Journal of Virology. — 2008. — Vol. 82 (15). — P. 7264 75 .

17 Gandhi S. Is the collapse of the respiratory center in the brain responsible for respiratory breakdown in COVID-19 patients? / S. Gandhi, A. Srivastava, U. Ray, P.P. Tripathi // ACS Chemical Neuroscience. — 2020. — Vol. 11, Issue 10. — P. $1379-1381$. https://doi.org/10.1021/acschemneuro.0c00217

18 Chen C. Advances in the research of cytokine storm mechanism induced by Corona Virus Disease 2019 and the corresponding immunotherapies / C. Chen, X. Zhang, Z. Ju, W.F. He // Chinese journal of burns. — 2020. — Vol. 36 (6). — E005. https://doi.org/10.3760/cma.j.cn501120-20200224-00088 
$19 \mathrm{Wu}$ Y. Nervous system damage after COVID-19 infection: presence or absence? / Y. Wu, X. Xu, L. Yang, L., C. Liu, C. Yang // Brain Behav Immun. — 2020. — Vol. 87. — P. 55. https://doi.org/10.1016/j.bbi.2020.04.043

20 Xiang P. First case of 2019 novel coronavirus disease with encephalitis / P. Xiang, X. Xu, L. Gao // New England Journal of Medicine. — 2020. — Vol. 382 (10). — Article ID 00015. https://doi.org/10.1056/NEJMoa2001191

21 Desforges M. Human Coronaviruses and Other Respiratory Viruses: Underestimated Opportunistic Pathogens of the Central Nervous System? / M. Desforges, A. Le Coupanec, P. Dubeau, A. Bourgouin, M. Dube, P.J. Talbot // Viruses. — 2019. — Vol. 12, № 1. - P. 14. https://doi.org/10.3390/v12010014

22 Negai N.A. Coronavirus infection COVID-19 in adults. Protocol \#143 of 05.07.2021 / N.A. Negai, K.S. Altynbekov, E.B. Shaikhyslamova // Ministry of Health of Republic of Kazakhstan.

23 Yang W. Clinical characteristics and imaging manifestations of the 2019 novel coronavirus disease (COVID-19): a multicenter study in Wenzhou city, Zhejiang, China / W. Yang, Q. Cao, L. Qin // J Infect. — 2020. — Vol. 80, Issue 4. — P. 388-393. https://doi.org/10.1016/j.jinf.2020.02.016

24 Ciaccio M. Biochemical biomarkers alterations in Coronavirus Disease 2019 (COVID-19) / M. Ciaccio, L. Agnello // Diagnosis. - 2020. — Vol. 7, No. 4. https://doi.org/10.1515/dx-2020-0057

25 Huang C. 6-month consequences of COVID-19 in patients discharged from hospital: a cohort study / C. Huang, L. Huang, Y. Wang // Lancet. — 2021. — Vol. 397 (10270). — P. 220-232. https://doi.org/10.1016/S0140-6736(20)32656-8

26 Ngai J.C. The long-term impact of severe acute respiratory syndrome on pulmonary function, exercise capacity and health status / J.C. Ngai, F.W. Ko, S.S. Ng // Respirology. — 2010. — Vol. 15. — P. 543-50.

27 Zhang P. Long-term bone and lung consequences associated with hospital-acquired severe acute respiratory syndrome: A 15year follow-up from a prospective cohort study / P. Zhang, J. Li, H. Liu // Bone Res. — 2020. — Vol. 8. — P. 8.

28 Wang F. Long-Term Respiratory and Neurological Sequelae of COVID-19 / F. Wang, R. Kream, G. Stefano // Med Sci Monit. — 2020. — Vol. 26. https://doi.org/10.12659/MSM.928996

29 Arbour N. Acute and persistent infection of human neural cell lines by human coronavirus OC43 / N. Arbour, G. Cote, C. Lachance // J Virol. — 1999. — Vol. 73. — P. 3338-3350.

30 Giacomelli A. Self-reported olfactory and taste disorders in SARS-CoV-2 patients: a cross-sectional study / A. Giacomelli, L. Pezzati, F. Conti // Clin Infect Dis. — 2020. — Vol. 71 (15). https://doi.org/10.1093/cid/ciaa330

31 Lechien J.R. Olfactory and gustatory dysfunctions as a clinical presentation of mild-to-moderate forms of the coronavirus disease (COVID-19): a multicenter European study / J.R. Lechien, C.M. Chiesa-Estomba, D.R. De Siati // Eur Arch Otorhinolaryngol. — 2020. — Vol. 277 (2). https://doi.org/10.1007/s00405-020-05965-1

\title{
З.Д. Кульбаева, Д.А. Клюев, Ш.С. Калиева \\ COVID-19 неврологиялық симптомдары мен салдары Қысқаша шолу
}

2019 жылдың желтоқсан айында Қытайдағы COVID-19 алғашқы ресми жағдайынан бастап, зерттеушілер бірнеше ішкі мүшелерге әсер ететін ауыр жедел респираторлық синдромның (SARSCoV-2) әсер ету механизмін ашуға тырысты. Бұл синдром адамда өкпе және қан айналымының өзгеруіне әкеледі, бұл тек өкпе жеткіліксіздігімен ғана емес, сонымен қатар басқа органдардың зақымдалуымен бірге өлімге әкелуі мүмкін. SARS-CoV-2-нің өкпеге тигізетін әсері үлкен және қорқынышты болғанымен, жүйке жүйесіне ұзақ мерзімді әсері айтарлықтай және одан да ауыр болып саналады, өйткені жүйке тінінің қалпына келуі қиын және ол жалпы мүгедектікке әкелуі мүмкін, себебі жүйке жүйесі бүкіл дененің функцияларын үйлестіреді. Барлық зерттеулер орталық жүйке жүйесінің кез келген жарақатының (жеңіл немесе ауыр) болуын көрсетеді, бірақ кейбіреулері сенімділік үшін одан әрі зерттеу қажет деп санайды. Бұл синдром адамда барлық зерттеулерде неврологиялық асқынулардың мүмкіндігін жоққа шығармайды, сонымен қатар, қосымша зерттеулер жүргізуді талап етеді.

Кілт сөздер: коронавирус, SARS-CoV-2, неврологиялық зардаптар, коронавирустың патогенезі.

\author{
3.Д. Кульбаева, Д.А. Клюев, Ш.С. Калиева \\ Неврологические симптомы и последствия COVID-19 \\ Миниобзор
}

C момента первого официального случая COVID-19 в Китае в декабре 2019 г. исследователи пытались раскрыть механизм действия тяжелого острого респираторного синдрома Coronavirus 2 (SARS$\mathrm{CoV}-2)$, который поражает несколько органов в дополнение к легким и вызывает изменения кровооб- 
ращения, способные привести к смерти не только из-за легочной недостаточности, но и поражения других органов. Хотя эффекты SARS-CoV-2 на легкие образцовые и пугающие, долгосрочные эффекты на нервную систему могут быть более значительными и даже серьезными, поскольку регенерация нервной ткани затруднена и может привести к общей инвалидности, так как нервная система координирует функции всего тела. Все исследования показывают наличие любого вида травмы (легкой или тяжелой) центральной нервной системы, но некоторые из них подчеркивают необходимость дальнейших исследований для большей уверенности. Авторы статьи приходят к выводу, что все исследования не исключают возможность существующих неврологических осложнений и, кроме того, требуют проведения дополнительных исследований.

Ключевые слова: коронавирус, SARS-CoV-2, неврологические последствия, патогенез коронавируса, поражение органов.

\section{References}

1 World Health Organization Coronavirus disease (COVID-19) situation report 102 (2020). Retrieved from https://www.who.int/emergencies/diseases/novel-coronavirus-2019/situation-reports/.

2 Filatov, A., Sharma, P., Hindi, F., \& Espinosa, P.S. (2020). Neurological complications of coronavirus disease (COVID-19): encephalopathy. Cureus, 12 (3), 7352. https://doi.org/10.7759/cureus.7352.

3 Munster, V., Koopmans, M., \& Doremalen, N. (2020). A novel coronavirus emerging in China-key questions for impact assessment. N. Engl. J. Med., 382 (8), 692-694. https://doi.org/10.1056/NEJMp2000929

4 Mao, L., Jin, H., \& Wang, M. (2020). Neurologic manifestations of hospitalized patients with coronavirus disease 2019 in Wuhan, China. JAMA Neurol., e201127. https://doi.org/10.1001/jamaneurol.2020.1127

5 Spinato, G., Fabbris, C., Polesel, J., Cazzador, D., Borsetto, D., Hopkins, C., \& Boscolo-Rizzo, P. (2020). Alterations in smell or taste in mildly symptomatic outpatients with SARS-CoV-2 infection. JAMA, e206771. https://doi.org/10.1001/jamaneurol.2020.6771

6 Helms, J., Kremer, S., Merdji, H., Schenck, M., Kummerlen, C., \& Collange, O., et al. (2020). Neurologic features in severe SARS-CoV-2 infection. N. Engl. J. Med., c2008597. https://doi.org/10.1056/NEJMc2008597

7 Kokil, Y.D., Raj, K.T.M., Samprathi, M., Sridhar, M., Adiga, R., \& Vemgal, P. (2021). Guillain-Barré syndrome associated with SARS-CoV-2. The Indian Journal of Pediatrics, 88 (5). https://doi.org/10.1007/s12098-021-03684-x

8 Kim, J.E., Heo, J.H., Kim, H.O., Song, S.H., Park, S.S., \& Park, T.H., et al. (2017). Neurological complications during treatment of middle east respiratory syndrome. J. Clin. Neurol., 13, 227-233. https://doi.org/10.3988/jen.2017.13.3.227

9 Manjunatha, N., Math, S.B., \& Kulkarni, G.B. (2011). The neuropsychiatric aspects of influenza/swine flu: A selective review. Ind. Psychiatry J., 20, 83-90.

10 Tsai, L., Hsieh, S., \& Chao, C. (2004). Neuromuscular disorders in severe acute respiratory syndrome. Arch. Neurol., 61, $1669-1673$.

$11 \mathrm{Wu}$, H., Zhuang, J., Stone, W.S., Zhang, L., Zhao, Z., \& Zongwen, W., et al. (2014). Symptoms and occurrences of narcolepsy: a retrospective study of 162 patients during a 10-year period in Eastern China. Sleep Med, 15 (6), $607-613$. https://doi.org/10.1016/j.sleep.2013.12.012

12 Miller, A., \& Arnold, A. (2019). The renin-angiotensin system in cardiovascular autonomic control: recent developments and clinical implications. Clinical Autonomic Research., 29 (2), 231-43. https://doi.org/10.1007/210286-018-0572-5

13 Gowrisankar, Y., \& Clark, M. (2016). Angiotensin II regulation of angiotensin-converting enzymes in spontaneously hypertensive rat primary astrocyte cultures. Journal of Neurochemistry, 138 (1), 74-85. https://doi.org/10.1111/jnc.13641

14 Koyuncu, O., Hogue, I., \& Enquist, L. (2013). Virus infections in the nervous system. Cell host \& Microbe, 13 (4); $379-93$.

15 Steardo, L., Zorec, R., \& Verkhratsky, A. (2020). Neuroinfection may contribute to pathophysiology and clinical manifestations of COVID-19. Acta Physiologica, 229 (3), e13473. https://doi.org/10.1111/apha.13473

16 Netland, J., Meyerholz, D., \& Moore, S. (2008). Severe acute respiratory syndrome coronavirus infection causes neuronal death in the absence of encephalitis in mice transgenic for human ACE2. Journal of Virology, 82 (15), 7264-75.

17 Gandhi, S., Srivastava A., Ray, U. \& Tripathi, P.P. (2020). Is the collapse of the respiratory center in the brain responsible for respiratory breakdown in COVID-19 patients? ACS Chemical Neuroscience, $11 \quad(10)$, 1379-1381. https://doi.org/10.1021/acschemneuro.0c00217

18 Chen, C., Zhang, X., Ju, Z., \& He, W.F. (2020). Advances in the research of cytokine storm mechanism induced by Corona Virus Disease 2019 and the corresponding immunotherapies. Chinese journal of burns, 36 (6), E005. https://doi.org/10.3760/cma.j.cn501120-20200224-00088

19 Wu, Y., Xu, X., Yang, L., Liu, C., \& Yang, C. (2020). Nervous system damage after COVID-19 infection: presence or absence? Brain Behav Immun., 87, 55. https://doi.org/10.1016/j.bbi.2020.04.043

20 Xiang, P, Xu, X, \& Gao, L. (2020). First case of 2019 novel coronavirus disease with encephalitis. New England Journal of Medicine, 382 (10), 00015. https://doi.org/10.1056/NEJMoa2001191 
21 Desforges, M., Le Coupanec, A., Dubeau, P., Bourgouin, A., Dube, M., \& Talbot, P.J. (2019). Human Coronaviruses and Other Respiratory Viruses: Underestimated Opportunistic Pathogens of the Central Nervous System? Viruses, 12 (1), 14. https://doi.org/10.3390/v12010014

22 Negai, N.A., Altynbekov, K.S., \& Shaikhyslamova, E.B. (2021). Coronavirus infection COVID -19 in adults. Protocol \#143 of 05.07.2021. Ministry of Health of Republic of Kazakhstan

23 Yang, W., Cao, Q., \& Qin, L. (2020). Clinical characteristics and imaging manifestations of the 2019 novel coronavirus disease (COVID-19): a multi-center study in Wenzhou city, Zhejiang, China. J Infect., 80 (4), 388-393. https://doi.org/10.1016/j.jinf.2020.02.016

24 Ciaccio, M., \& Agnello, L. (2020). Biochemical biomarkers alterations in Coronavirus Disease 2019 (COVID-19). Diagnosis, 7 (4). https://doi.org/10.1515/dx-2020-0057

25 Huang, C., Huang, L., \& Wang, Y. (2021). 6-month consequences of COVID-19 in patients discharged from hospital: a cohort study. Lancet, 397 (10270), 220-232. https://doi.org/10.1016/S0140-6736(20)32656-8

26 Ngai, J.C., Ko, F.W., \& Ng, S.S. (2010). The long-term impact of severe acute respiratory syndrome on pulmonary function, exercise capacity and health status. Respirology, 15, 543-50.

27 Zhang, P., Li, J., \& Liu, H. (2020). Long-term bone and lung consequences associated with hospital-acquired severe acute respiratory syndrome: A 15-year follow-up from a prospective cohort study. Bone Res. 8, 8 .

28 Wang, F., Kream, R., \& Stefano, G. (2020). Long-Term Respiratory and Neurological Sequelae of COVID-19. Med Sci Monit., 26. https://doi.org/10.12659/MSM.928996

29 Arbour, N., Cote, G., \& Lachance, C. (1999). Acute and persistent infection of human neural cell lines by human coronavirus OC43. J Virol., 73, 3338-3350.

30 Giacomelli, A., Pezzati, L., \& Conti, F. (2020). Self-reported olfactory and taste disorders in SARS-CoV-2 patients: a crosssectional study. Clin Infect Dis., 71 (15). https://doi.org/10.1093/cid/ciaa330

31 Lechien, J.R., Chiesa-Estomba, C.M., \& De Siati, D.R. (2020). Olfactory and gustatory dysfunctions as a clinical presentation of mild-to-moderate forms of the coronavirus disease (COVID-19): a multicenter European study. Eur Arch Otorhinolaryngol., 277 (2). https://doi.org/10.1007/s00405-020-05965-1 